\title{
Recent advances in the gene map of inherited eye disorders: primary hereditary diseases of the retina, choroid, and vitreous
}

\author{
Philip J Rosenfeld, Victor A McKusick, Joanna S Amberger, Thaddeus P Dryja
}

The diagnosis and basic understanding of many genetic ocular disorders have been aided by the identification of the disease causing chromosomal loci. These chromosomal loci have been mapped using the candidate gene or the positional cloning approaches. This review will focus on genetic disorders that primarily affect ocular function with emphasis on the most recent advances in the chromosomal mapping of these disorders. In particular, we will concentrate on the genetic diseases affecting the posterior segment of the eye including the retina, choroid, and vitreous. The success of linkage analysis has relied heavily on previous clinical classifications and there are numerous reports of distinct ocular diseases mapping to specific chromosomal loci. However, there are also many examples in which a well defined disease maps to any of a number of chromosomal loci. This genetic phenomenon is known as non-allelic or locus heterogeneity and can be viewed as reflecting the eye's limited repertoire of responses to a variety of genetic lesions. Another emerging pattern is that of "gene sharing" in which different mutations within the same gene can cause clinically distinct ocular diseases. Mapping of mendelian genetic disorders has helped refine the clinical classifications and has led to examples of both "lumping" and "splitting".

\section{Howe Laboratory, \\ Department of \\ Ophthalmology, \\ Harvard Medical \\ School, Massachusetts \\ Eye and Ear \\ Infirmary, 243 Charles \\ Street, Boston, \\ Massachusetts 02114, \\ USA \\ P J Rosenfeld \\ T P Dryja}

Center for Medical Genetics, The Johns Hopkins University School of Medicine, Blalock Building, Room 1007, $600 \mathrm{~N}$ Wolfe Street,

Baltimore, Maryland,

21287-4922, USA

V A McKusick

J S Amberger

Correspondence to Dr Rosenfeld.

\section{Ocular tumours}

RETINOBLASTOMA

Retinoblastoma, an embryonic neoplasm of the retina, is the most common primary intraocular malignancy in infants and children. The average annual incidence of retinoblastoma in the US population younger than 10 years old is 10.9 per million. ${ }^{1}$ The gene maps to chromosome 13q14, consists of 27 exons spanning 180 to $388 \mathrm{bp}$ of genomic DNA, produces a $4.7 \mathrm{~kb}$ transcript, and encodes a nuclear phosphoprotein consisting of 928 amino acids. The complete gene sequence is available. ${ }^{2}$ The retinoblastoma $(\mathrm{Rb})$ gene is a model for a class of recessive cancer genes where wild type alleles have a tumour suppressor function. Retinoblastoma predisposition segregates as an autosomal dominant trait with $90 \%$ penet- rance, but the mutations are actually recessive at the cellular level since tumours arise only if both copies of the retinoblastoma gene are inactivated in a sensitive cell. These tumour inducing null mutations can arise by intragenic deletion, insertion, or translocation, by single nucleotide changes that affect coding or splicing sequences, or by epigenetic abnormalities such as hypermethylation of the promoter region. $^{3-13}$ Some retinoblastoma families show evidence of reduced or incomplete penetrance. The molecular basis of reduced penetrance has been investigated in eight different families. ${ }^{14-17}$ Two families with reduced penetrance have mutations in the promoter region of the retinoblastoma gene that decrease but do not eliminate the $\mathrm{Rb}$ gene product and three families have a mutation that produces a mutant protein with presumed diminished tumour suppressor activity. One of the families studied actually has "pseudo-low penetrance" owing to independently derived $\mathrm{Rb}$ mutations in distant relatives. ${ }^{17}$ In another two families, no common intragenic haplotypes were identified in relatives with retinoblastoma and no mutations were identified in the $\mathrm{Rb}$ genes. ${ }^{16}$ These two families could be other examples of "pseudolow penetrance" with relatives having independently derived $\mathrm{Rb}$ mutations.

\section{Colour blindness}

PROTAN AND DEUTAN SERIES

The red and green visual pigment genes have been cloned, sequenced, and mapped. ${ }^{18-20}$ Mutations in these genes are the molecular basis for $\mathrm{X}$ linked colour vision abnormalities. ${ }^{21-23}$ Genes for the red and green opsins lie on the long arm of the $\mathrm{X}$ chromosome within Xq28. These genes are arranged in a tandem array with one copy of the red pigment gene at the $5^{\prime}$ end and from one to five green pigment genes located downstream in a head to tail configuration presumably arising from unequal homologous recombination events. Only a single green pigment gene is expressed from this locus, probably the most proximal copy. ${ }^{24}$ More than $95 \%$ of cases of red-green colour blindness arise from mutant genotypes owing to unequal intra- and intergenic re- 
combination events giving rise to deletions or hybrid genes within the tandem array of pigment genes. ${ }^{215-28}$ These mutations are the genetic basis for protanopia (absence of red colour vision), protanomaly (anomalous red colour vision), deuteranopia (absence of green colour vision), and deuteranomaly (anomalous green colour vision). A missense mutation within the human green visual pigment gene is another cause of deuteranomaly. ${ }^{29}$ There is a direct correlation between anomalous red/green vision as detected by psychophysical experiments and the shifts in the in vitro absorption maxima of hybrid pigments produced from cloned cDNAs when compared to normal cone pigments. ${ }^{30-32}$ In normal trichromats who display person to person variability in red colour matching, two common alleles of the red pigment gene have been identified and the respective shifts in their absorption maxima can account for the differences in psychophysical testing. ${ }^{32-34}$ In general, persons with abnormalities in red-green discrimination have no other signs of retinal disease.

The complete loss of red and green cone function results in blue cone monochromacy, also known as incomplete achromotopsia. Males with this $\mathrm{X}$ linked trait use blue cones exclusively under photopic conditions and generally have an acuity of only around 20/200. These persons are capable of limited hue discrimination but only at intermediate light levels. ${ }^{3536}$ Blue cone monochromats have rearrangements within the red and green visual pigment gene cluster that result in the functional loss of both classes of opsin genes. ${ }^{3738}$ These mutations fall into two classes. In one class, the loss of functional genes is mediated by unequal homologous recombination and point mutations. A second class involves the deletion of a locus control region upstream of the red and green pigment gene cluster. The affected upstream region can normally function as an activator of cone specific gene expression in transgenic mice. ${ }^{39}$

\section{TRITANOPIA}

Tritanopia, the absence of blue colour vision, differs from the other colour vision disorders because it is inherited as an autosomal dominant trait with variable penetrance. The gene encoding the cone blue sensitive pigment has been cloned, sequenced, and mapped to chromosome 7 at position $7 \mathrm{q} 31.3-\mathrm{q} 32 .{ }^{182140}$ Point mutations within the blue pigment gene have been associated with tritanopia. ${ }^{1142}$

\section{ROD MONOCHROMACY}

The absence of functional cones is known as total achromatopsia or rod monochromacy. This condition is inherited as an autosomal recessive trait. Rod monochromatism is characterised by nystagmus in infancy that diminishes with age. There is severe photophobia and poor vision in ordinary lighting. Vision is improved with dim light to $20 / 200$ but there is a total absence of colour discrimination. The fundus examination is normal but histo- pathological studies of eyes from patients show abnormal or absent cones. ${ }^{43}$ There is evidence that the genetic locus for rod monochromacy is on chromosome $14 .^{44}$ In this report, a 20 year old white woman with rod monochromacy was found to have a 14;14 Robertsonian translocation and shown to be isodisomic for the maternal chromosome 14 . The responsible locus on chromosome 14 has not been identified.

\section{Congenital stationary night blindness}

Congenital stationary night blindness (CSNB) is a group of genetically heterogeneous retinal disorders characterised by non-progressive night blindness. The disease can be inherited as an autosomal dominant, autosomal recessive, or $\mathrm{X}$ linked trait, and there can be phenotypic heterogeneity even between families with the same inheritance pattern. Electroretinographic evidence indicates an intact cone system but the rod system can be variably affected. The complete type has no detectable rod function, while the incomplete type has reduced rod function. Reduced visual acuity and nystagmus are variable clinical features of this disease. Myopia is often associated with $\mathrm{X}$ linked and recessive forms. A dominant form of CSNB can be caused by certain missense mutations in the rhodopsin gene. ${ }^{45-47}$ These mutations are distinct from those responsible for retinitis pigmentosa, a progressive degeneration of both rods and cones. Dryja et a $l^{46}$ could not find a rhodopsin mutation in a subject with the Nougaret type of CSNB, perhaps the most thoroughly studied form of autosomal dominant CSNB. A type of CSNB usually associated with myopia, nystagmus, and decreased visual acuity has been designated CSNB1 and mapped to the short arm of the $\mathrm{X}$ chromosome at position Xp11.3. ${ }^{48-51}$ The frequent occurrence of myopia in this disorder is believed to be a pleiotropic effect of the unidentified CSNB gene rather than the result of a closely linked second gene. ${ }^{51}$ The gene for CSNB1 might be allelic with unidentified genes responsible for retinitis pigmentosa and ocular albinism which have been assigned to the same region by linkage studies. ${ }^{52-56}$

\section{Ocular albinism}

Nettleship-Falls type ocular albinism or ocular albinism type 1 (OA1) is inherited as an $\mathrm{X}$ linked recessive disorder. The fundamental abnormality is believed to be defective melanogenesis within all pigment-containing cells, but the pigmentation appears grossly abnormal only in the eye. Affected males present with decreased visual acuity, nystagmus, and head nodding. Examination shows hypopigmentation of the fundus, foveal hypoplasia, prominent choroidal vessels, iris translucency, posterior embryotoxon, and optic disc hypoplasia. ${ }^{57}$ Visual evoked potentials show evidence of abnormal crossing of the optic nerves at the chiasm. Carrier females may show iris translucency, pigment mottling at the fundus periphery, and abnormal macromelanosomes 
on histological inspection of skin biopsies. Multipoint linkage analysis and comparative deletion mapping have refined the location of the OA1 gene within $\mathrm{Xp} 22.3 .^{58-61}$ This same region has been linked to a form of $\mathrm{X}$ linked recessive ocular albinism with late onset progressive sensorineural hearing loss. ${ }^{62}$ Both forms of ocular albinism may be clinical manifestations of different genes or the result of allelic heterogeneity within the same gene. While the gene for OA1 has not yet been identified, it has been localised within a $200 \mathrm{~kb}$ region that is contained within a $2.6 \mathrm{Mb}$ yeast artificial chromosome contig. ${ }^{63}$

Forsius-Eriksson type ocular albinism or ocular albinism type 2 (OA2) was originally described in a family from the Åland Islands in the Sea of Bothnia. This form of ocular albinism is referred to as Åland Island eye disease (AIED). OA2 or AIED is inherited as an $\mathrm{X}$ linked recessive disorder. This form of ocular albinism has the clinical characteristics described for OA1. In addition, affected males with OA2 often have progressive axial myopia, astigmatism, defective dark adaptation, and protanomalous colour blindness. In contrast to $\mathrm{OA} 1$, the pigment containing cells in OA2 appear normal and there is no evidence of optic nerve fibre misrouting at the chiasm. Based on electrophysiological techniques, OA2 has been considered by some to be a form of congenital stationary night blindness with myopia (CSNB1). ${ }^{5664}$ The gene for OA2 was mapped by multilocus linkage analysis to the proximal region of $\mathrm{Xp}(\mathrm{Xp} 11.3),{ }^{54-56}$ the same region implicated in typical $\mathrm{X}$ linked congenital stationary night blindness with myopia and a form of retinitis pigmentosa. The possibility exists that $\mathrm{OA} 2$, congenital stationary night blindness, and retinitis pigmentosa are allelic. There is a discrepancy between mapping of OA2 to $\mathrm{Xp11.3}$ and the finding that a patient with the clinical characteristics of OA2 and Duchenne muscular dystrophy carries a deletion of Xp21.3-21.2. ${ }^{6566}$ This finding would support the presence of an additional locus on the $\mathrm{X}$ chromosome for ocular albinism that closely resembles OA2.

A third form of ocular albinism (OA3) is inherited as an autosomal recessive disorder. This may be the genetic type found in most isolated cases of females with ocular albinism. OA 3 is phenotypically similar to OA2 except that males and females are equally affected. Deletion analysis of one patient with OA3 has permitted a tentative chromosomal assignment to the q13-q15 region of chromosome $6 .^{67}$

\section{Retinitis pigmentosa}

Retinitis pigmentosa (RP) is a set of genetic diseases that feature progressive photoreceptor degeneration. Tunnel vision caused by the early loss of peripheral photoreceptors is one hallmark of this disease. As the disease progresses, central vision is lost as well. On examination, middle aged patients with $\mathrm{RP}$ classically have fundus changes that include peripheral intraretinal pigmentation known as bone spicules, retinal vessel attenuation, and optic nerve head pallor. Diagnosis often depends upon full field electroretinographic testing, dark adaptation threshold testing, and evaluation of visual fields. The disease is genetically heterogeneous and can be inherited as an autosomal dominant, autosomal recessive, or $\mathrm{X}$ linked trait. Affected subjects without a family history of RP are designated as isolate or simplex cases. Most isolate cases are probably recessive cases although some may be $\mathrm{X}$ linked cases or new dominant mutations. Populations differ in the prevalence of each genetic type, but the recessive and isolate types usually account for the majority of cases. ${ }^{68}$ Autosomal recessive $R P$ in association with hearing loss is known as Usher syndrome and will be discussed separately. At least 11 chromosomal regions have been implicated as containing genes causing RP, and four of the genes have been identified. The numerical designation for each locus (for example, RP-1, RP-2, etc) used by $\mathrm{McKu}$ sick in Mendelian inheritance in man (11th edition, 1994) and its online version (OMIM) has only categorical significance and does not correlate with disease severity, chronological order of gene identification, or population prevalence. ${ }^{69}$

The first RP locus mapped was for an $\mathrm{X}$ linked form of the disease. ${ }^{70}$ Subsequent linkage and heterogeneity analyses support the existence of at least two loci on the $\mathrm{X}$ chromosome that are associated with $R P^{71}$ These unidentified loci have been designated RP-2 and $\mathrm{RP}$-3. RP-2 was localised within Xp11.3p11.22 by polymorphic microsatellite analysis, ${ }^{52}$ with the most likely position at Xp11.23. ${ }^{53}$ The RP-3 locus was localised to Xp21.1 by multipoint linkage analysis. ${ }^{7273}$ Linkage data from a single family was suggestive of a third locus at position Xp21.3-p21.2 and designated RP-6. ${ }^{71}$ However, deletion mapping data do not support the location of this third locus. ${ }^{74}$ Kaplan et $a l^{75}$ propose that RP-2 and RP-3 can be distinguished clinically. Patients with RP-2 are reported to have early onset night blindness and severe myopia whereas RP-3 patients have later onset night blindness and little if any myopia. ${ }^{76}$ Other groups believe that the wide clinical variation in $\mathrm{X}$ linked $\mathrm{RP}$ makes genetic locus identification on the basis of clinical features problematical. ${ }^{53}$

Using the candidate gene approach, Dryja $e t$ $a l^{778}$ identified mutations in the rhodopsin gene as a cause of autosomal dominant RP. Since these first reports of rhodopsin mutations, at least 60 different rhodopsin mutations have been identified and rhodopsin mutations are now known to account for about $25 \%$ of autosomal dominant cases. ${ }^{79-105}$ The rhodopsin locus maps to chromosome $3 \mathrm{q} 21-\mathrm{q} 24$ and is designated as RP-4.

Mutations within the peripherin/RDS gene were also reported as a cause of autosomal dominant RP. ${ }^{82}{ }^{106-111}$ The peripherin/RDS gene was selected for screening because mutations in the homologous mouse gene called $r d s$ causes a slow form of retinal degeneration in mice. To date, mutations in the peripherin/RDS gene are estimated to account for approximately 3 to $5 \%$ of the autosomal dominant cases. 
Interestingly, different mutations within the peripherin/RDS gene can cause a variety of clinically distinct disorders including retinitis punctata albescens, ${ }^{112}$ vitelliform macular dystrophy, ${ }^{108}$ macular dystrophy, ${ }^{108}$ and pattern pigment dystrophy of the fovea. ${ }^{113114}$ There is phenotypic variation even within a family segregating a peripherin/RDS mutation, with affected relatives in one pedigree having either retinitis pigmentosa, pattern dystrophy, or fundus flavimaculatus. ${ }^{109}$ The peripherin/RDS gene maps to chromosome $6 \mathrm{p} 21.1-$ cen $^{115116}$ and is designated RP-7.

A third locus for autosomal dominant RP has been mapped to the pericentric region of chromosome 8 between $8 \mathrm{p} 11$ and $8 \mathrm{q} 21 .^{117}$ This locus is designated RP-1 and the gene is not yet identified. Linkage analyses have implicated unidentified loci on $7 p(R P-9)$ and $7 q$ (RP10), each assignment based on one autosomal dominant pedigree to date. ${ }^{118118 \mathrm{~A} 119} \mathrm{~A}$ sixth dominant locus (RP-8) has been mapped to chromosome $19 \mathrm{q} 13.4 .{ }^{120}$ Linkage exclusion of all the previously identified loci in one family with autosomal dominant $\mathrm{RP}$ and hearing loss suggests the existence of at least one additional gene for autosomal dominant RP. ${ }^{120121}$

There are at least three loci where mutations can cause autosomal recessive RP. The candidate gene approach was used to identify these mutations. Recessive RP can be caused by a null mutation in the rhodopsin gene and by mutations in the $\beta$ subunit of the rod cGMP phosphodiesterase. ${ }^{122-125}$ Additional recessive mutations have been identified in the gene for the rod cGMP activated channel protein. ${ }^{126}$

\section{Retinitis pigmentosa and hearing loss} USHER SYNDROMES

The autosomal recessive forms of retinitis pigmentosa associated with hearing loss are known as the Usher syndrome. The Usher syndrome is phenotypically and genetically heterogeneous. It accounts for about $15 \%$ to $20 \%$ of patients with retinitis pigmentosa and $50 \%$ of patients with combined deafness and blindness. Patients with Usher syndrome type I have retinitis pigmentosa, profound congenital sensorineural deafness, and vestibular ataxia. The retinitis pigmentosa usually becomes symptomatic within the first two decades of life. Usher syndrome type II is characterised by retinitis pigmentosa, partial acquired hearing impairment, and no ataxia. The retinitis pigmentosa usually becomes symptomatic in early adulthood. Not only is there non-allelic heterogeneity between Usher syndrome types I and II, but there is non-allelic heterogeneity within each type of Usher syndrome. At least five different chromosomal loci have been inferred from linkage studies. One locus for Usher syndrome type I is chromosome 14q32.1-q32.3 based on a study of 10 French families. ${ }^{127}$ This genetic form of Usher syndrome is designated USH1A. Two additional loci have been mapped to chromosome $11 .^{128-130}$ One locus is at position 11q13.5 (USH1B) and was found among British pedigrees. The other locus was found in French-Acadian families and localises to the interval 11p15.2-p14 (USH1C). Some but not all Usher syndrome type II families are linked to markers on chromosome 1 between 1q42-qter (USH2A). ${ }^{131-134}$ A candidate gene for Usher syndrome type II was a choroideremia-like (CHML) gene that maps to chromosome 1q42-qter. ${ }^{133}$ Single strand conformation polymorphism analysis and direct sequencing of the CHML gene in patients with USH2A did not identify any disease specific mutations. The gene responsible for any form of Usher syndrome has not as yet been identified.

Recently, the locus for another form of syndromic autosomal recessive $R P$, the BardetBiedl syndrome, was linked to the long arm of chromosome 16 between regions q13 and q22. ${ }^{135136}$ In addition to retinitis pigmentosa, this disorder is characterised by mental retardation, obesity, polydactyly, syndactyly, and hypogonadism. The chromosome $16 \mathrm{q}$ locus was excluded from two additional unrelated families with Bardet-Biedl syndrome. This syndrome provides yet another example of nonallelic heterogeneity in families with clinically indistinguishable diseases.

\section{Retinal dystrophies}

CONE DEGENERATIONS

Cone degenerations can be inherited as autosomal dominant, autosomal recessive, or $\mathrm{X}$ linked disorders. The disorders are phenotypically heterogeneous but usually present with decreased central visual acuity, fine nystagmus, defective colour vision, and photophobia. Unlike the retinitis pigmentosa syndromes, cone degenerations usually present with intact peripheral vision and night vision. Night blindness and peripheral field loss can develop, especially in the cone-rod dystrophies. On examination, these patients may have normal appearing fundi or they may have central retinal pigment epithelial changes and an associated macular lesion with the appearance of a bull's eye. The diagnosis usually depends on full field electroretinographic testing, colour testing, and dark adaptation threshold testing to evaluate cone function. Using the candidate gene approach, Reichel et al ${ }^{137}$ identified the first genetic mutation responsible for a cone degeneration. In this $\mathrm{X}$ linked pedigree, affected males and carrier females were found to have a $6.5 \mathrm{~kb}$ deletion within the red pigment gene at position $\mathrm{Xq} 28$. Another locus for $\mathrm{X}$ linked cone dysfunction was reportedly mapped by linkage analysis to the region $\mathrm{Xp} 21$ p11.1. ${ }^{138138 \mathrm{~A}} \mathrm{~A}$ possible locus for an autosomal dominant form of cone dystrophy was proposed to be on chromosome 6 in the region q25-q26 based on the identification of a translocation. ${ }^{139}$ Another photoreceptor dystrophy involving both cones and rods called cone-rod dystrophy (CRD) has been localised to chromosome 18q21.1-q21.3 by deletion mapping of mentally retarded children with this disorder. ${ }^{140}$ More recently, Evans et al ${ }^{141}$ mapped a locus for autosomal dominant CRD to chromosome 19q13.1-q13.2 in another family. A third locus on chromosome $17 \mathrm{q}$ has been proposed be- 
Genetic mapping of primary ocular diseases involving the retina, chorid, and vitreous

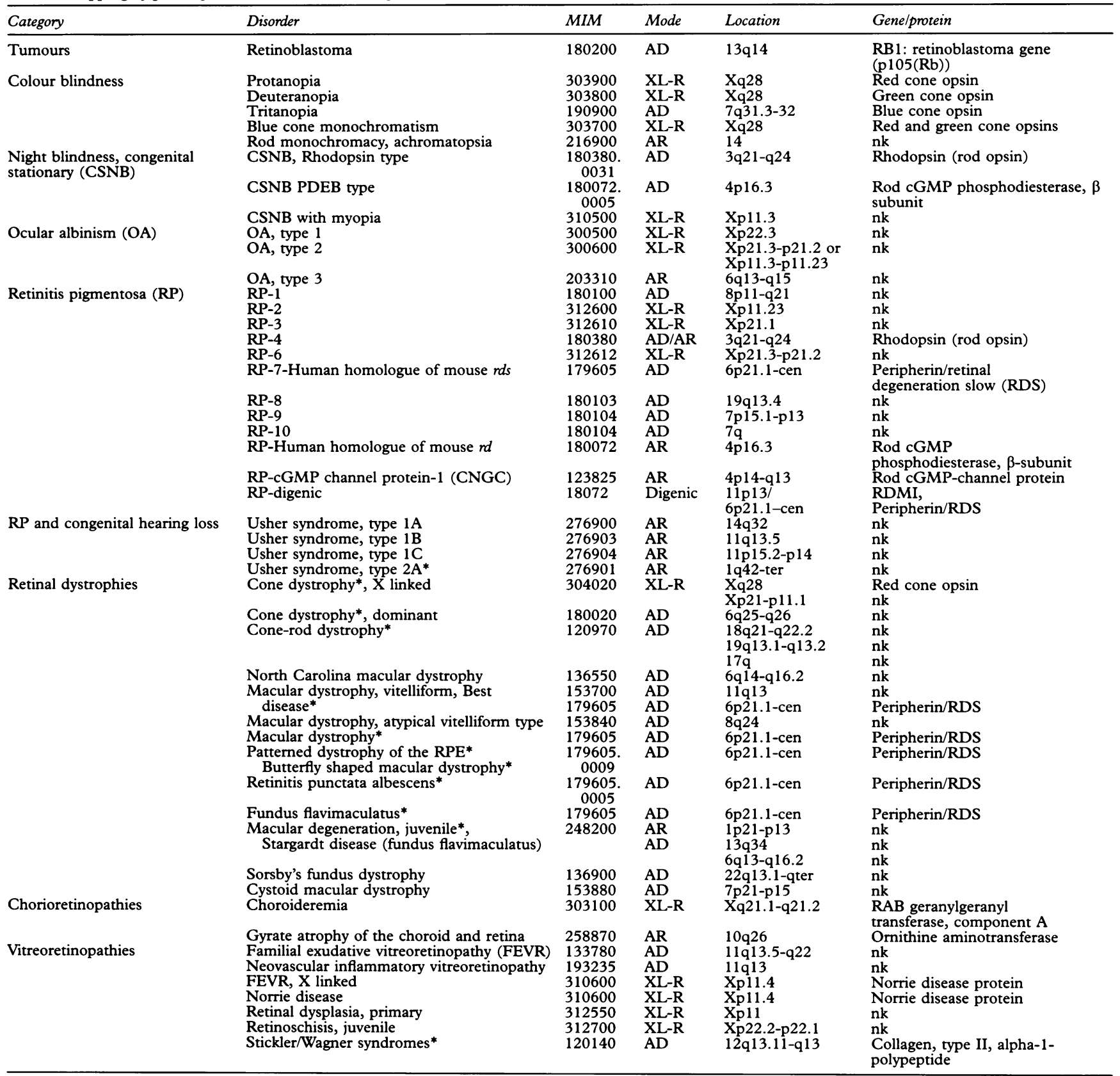

nk: not known, AD: autosomal dominant, AR: autosomal recessive, XL-R: X linked recessive, *non-allelic heterogeneity, MIM: Mendelian inheritance in man (11th edition, 1994)

cause one case of CRD also had neurofibromatosis type $\mathrm{I} .{ }^{142}$

\section{MACULAR DYSTROPHIES}

North Carolina macular dystrophy is an autosomal dominant macular dystrophy with onset during infancy. The disease is usually nonprogressive. The phenotype is completely penetrant but the expressivity is highly variable. Generally, the macular lesions are bilateral and symmetrical. The unidentified locus responsible for this disorder designated MCDR1 has been mapped to chromosome $6 \mathrm{q} 16^{143-145}$

A distinct macular dystrophy, Best disease or vitelliform macular dystrophy, is characterised by the early onset of a confluent yellow mass resembling an egg yolk within the macula. Over time, the vitelliform lesion becomes increasingly non-confluent and variably pig- mented with accompanying atrophy of the retinal pigment epithelium. Funduscopic changes precede visual impairment. Central visual loss is progressive. Electro-oculography can be used to identify affected persons even before the onset of fundus abnormalities. The unidentified gene responsible for this disorder has been mapped to chromosome $11 \mathrm{q} 13$ by linkage analysis. ${ }^{146}$ A form of retinal dystrophy known as atypical vitelliform macular dystrophy involves the peripheral and peripapillary retina more extensively than Best disease and the yellow lesions tend to be smaller. This disease was mapped by linkage analysis to chromosome $8 \mathrm{q} 24 .{ }^{147}$ A retinal dystrophy with macular vitelliform lesions similar to Best disease has been associated with mutations in the peripherin/RDS gene. ${ }^{108113}$ Other autosomal dominant retinal dystrophies associated with mutations in the peripherin/RDS 

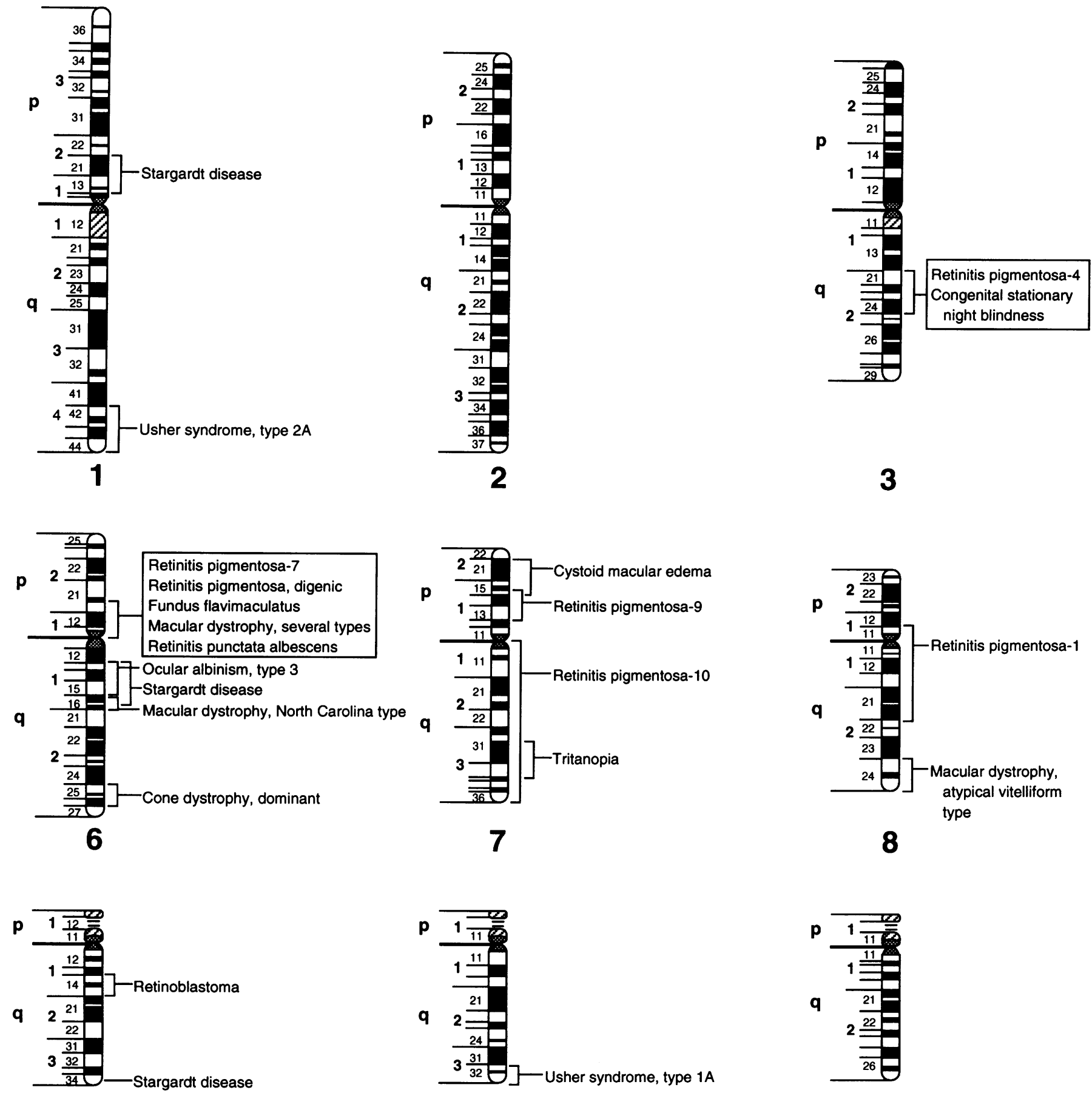

13

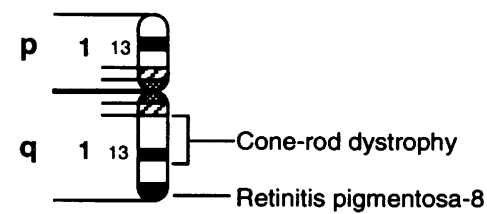

19
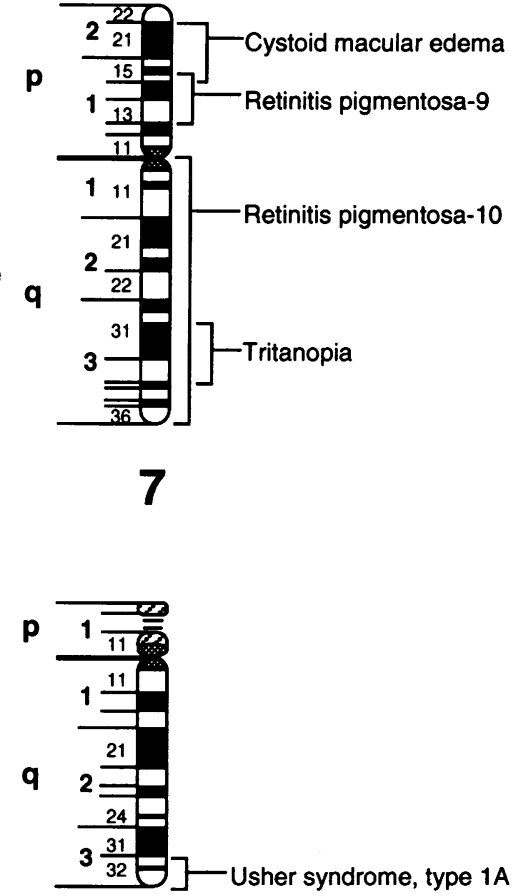

14 Rod monochromacy

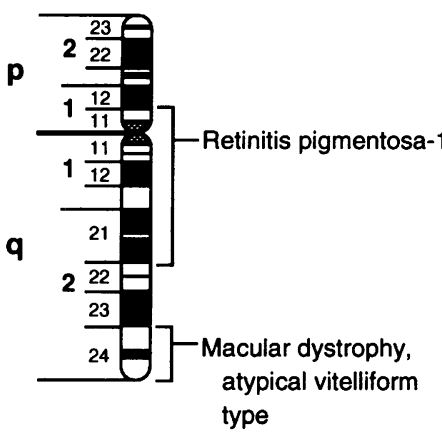

8

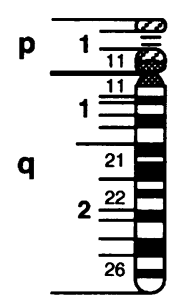

15

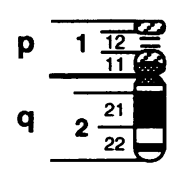

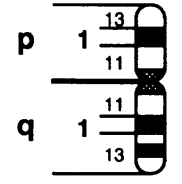


FIGURE 1

THE HUMAN GENE MAP

Primary ocular diseases involving the retina, choroid, and vitreous

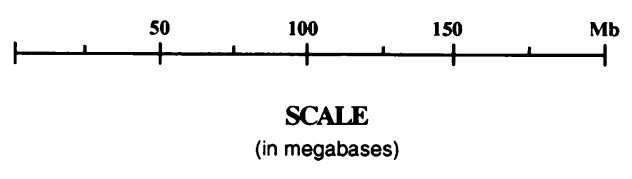

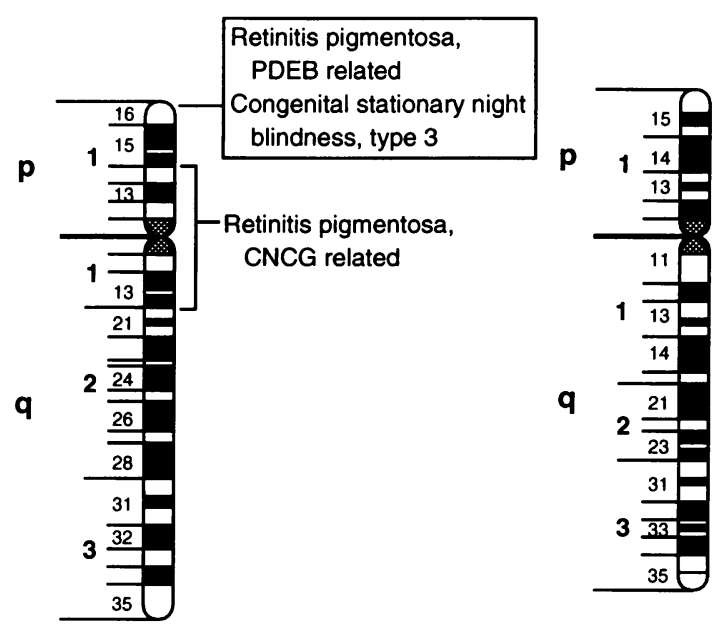

4

5
(1)

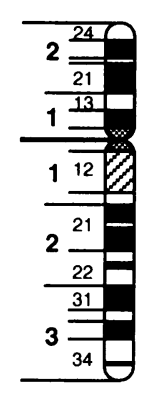

9

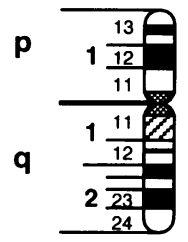

16
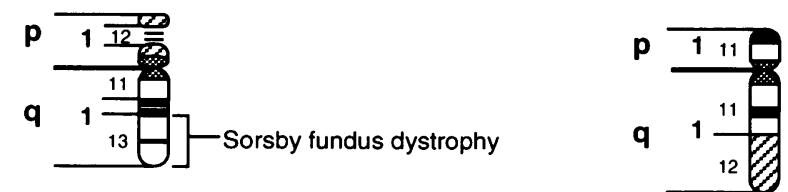

22

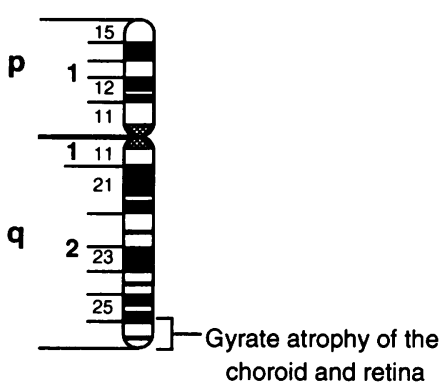

10

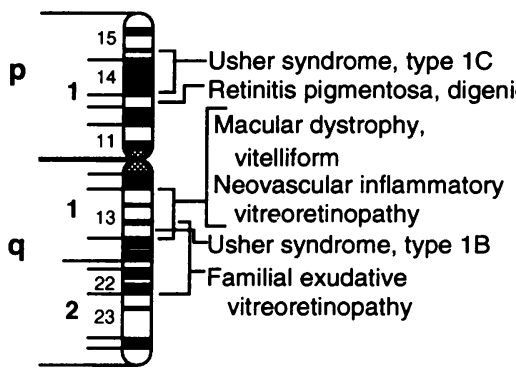

11

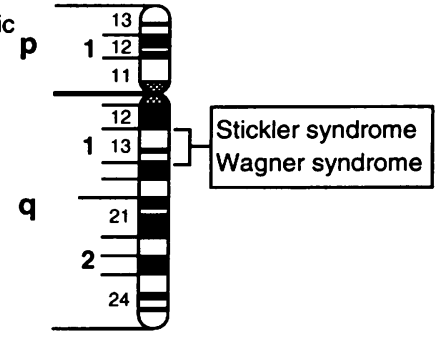

12

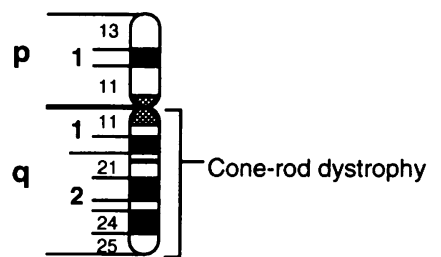

17

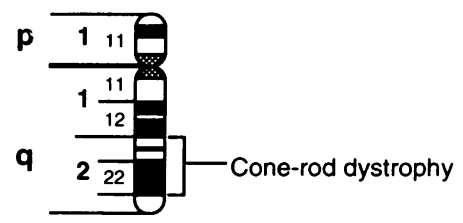

18

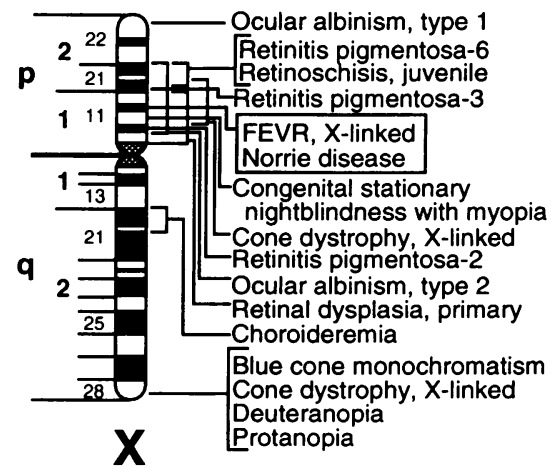


gene include butterfly shaped pattern dystrophy, ${ }^{109113114148}$ macular dystrophy, ${ }^{108}$ retinitis punctata albescens, ${ }^{112}$ and fundus flavimaculatus. ${ }^{109}$ An autosomal recessive form of fundus flavimaculatus with juvenile onset and severe progressive visual loss known as Stargardt disease has recently been mapped to the short arm of chromosome $1 .{ }^{149150}$ Autosomal dominant forms of this disease have been mapped to chromosome $13 \mathrm{q} 34^{151}$ and to the long arm of chromosome 6 between loci D6S313 (6q13-q16.2) and D6S252 (6q14q16.2). ${ }^{152}$ Linkage to the North Carolina macular dystrophy gene on chromosome 6 was excluded in this family with autosomal dominant Stargardt-like disease.

\section{Chorioretinopathies \\ CHOROIDEREMIA}

Choroideremia (CHM), an $\mathrm{X}$ linked recessive disorder, causes constriction of peripheral vision and reduction of night vision. There is progressive loss of central vision leading to blindness usually in the fourth to fifth decade of life owing to progressive degeneration of the retina, the retinal pigment epithelium, and the choroid. While heterozygous women are usually asymptomatic, they may have irregularly pigmented fundi and peripapillary chorioretinal atrophy. Rarely, they may also lose vision. The disease locus was mapped to band Xq21 by both linkage analysis of pedigrees and cytogenetic analysis of patients with detectable chromosomal translocations and deletions. ${ }^{153154}$ Mutations in a gene encoded within this region, the CHM gene, have been identified in families with choroideremia. ${ }^{153-158}$ The predicted sequence of the putative CHM gene product was found to be homologous to a bovine protein that inhibits the exchange of GTP for bound GDP on Rab 3A, known as Rab3A-GDP dissociation inhibitor (Rab3AGDI). ${ }^{159-161}$ Subsequently, the CHM gene was found to be homologous to component $\mathrm{A}$ of rat $\mathrm{Rab}$ geranylgeranyl transferase. ${ }^{162}$ Further support for the function of the CHM gene product was obtained by showing functional deficiency of Rab geranylgeranyl transferase component A from lymphoblast extracts prepared from choroideremia patients. ${ }^{163}$ Supplementation of these extracts with wild type component A restored normal levels of geranylgeranyl transferase activity supporting the conclusion that the choroideremia gene encodes at least one form of component $A$.

\section{GYRATE ATROPHY}

Gyrate atrophy is an autosomal recessive retinal degeneration that is usually diagnosed in late childhood. The characteristic fundus lesions are sharply demarcated circular areas of chorioretinal atrophy in the periphery of the retina. Early peripapillary atrophy and myopia may also be evident. Other clinical findings include constricted visual fields, raised dark adaptation thresholds, and small or non-detectable electroretinographic responses. During the second and third decades of life, the scalloped edges of chorioretinal degeneration progress towards the posterior pole. One hallmark of this disease is hyperornithaemia which can be partially alleviated in some patients by the administration of pyridoxine (vitamin B6). A deficiency of the mitochondrial enzyme ornithine aminotransferase (OAT) in patients with gyrate atrophy was first identified by Valle et al. ${ }^{164}$ This is one of the few genetic eye disorders where the discovery of a biochemical defect preceded the molecular genetic identification of mutations. ${ }^{165166}$ Using cDNA probes encoding OAT, Ramesh et $a l^{167}$ and Barrett et $a l^{168}$ mapped the gene to chromosome $10 \mathrm{q} 26$ and family linkage data supported this locus as the cause of gyrate atrophy. ${ }^{169} 170$ The OAT structural gene was shown to span 21 kilobases and encode a $2 \cdot 2$ kilobase mRNA consisting of 11 exons. ${ }^{171}$ Numerous mutations within the gyrate atrophy gene have been reported and extensive allelic heterogeneity exists in both the vitamin B6 responsive and non-responsive phenotypes. ${ }^{166172-187}$ Unlike many hereditary ocular diseases where the defective genes are expressed primarily in the affected tissues, OAT is expressed throughout the body. The reason systemic defects in OAT lead specifically to degeneration of the choroid and retina is unknown.

\section{Vitreoretinopathies}

FAMILIAL EXUDATIVE VITREORETINOPATHY, NEOVASCULAR INFLAMMATORY

VITREORETINOPATHY, NORRIE DISEASE, AND

PRIMARY RETINAL DYSPLASIA

Familial exudative vitreoretinopathy (FEVR) can be inherited as an autosomal dominant or $\mathrm{X}$ linked recessive disease. The disease shows nearly $100 \%$ penetrance but variable expressivity with onset any time from infancy to late adulthood. FEVR closely resembles retinopathy of prematurity but there is no history of premature birth or oxygen therapy. The disease is characterised by incomplete vascularisation of the peripheral retina with atypical vessels lying adjacent to a more anterior avascular zone. Retinal exudation, neovascularisation, and fibrovascular proliferation develop at the periphery followed by traction and exudative retinal detachments, falciform retinal folds, a "dragged disc" and macula, and vitreous haemorrhage. Patients with FEVR usually reach a stationary stage and total blindness is uncommon. A locus for autosomal dominant FEVR was mapped by linkage analysis to chromosome 11q13.5-q22. ${ }^{188} 189$ Autosomal dominant neovascular inflammatory vitreoretinopathy (ADNIV) is another disease characterised by traction retinal detachment. Linkage analysis has mapped this disorder to chromosome 11q13, the same region as autosomal dominant FEVR, ${ }^{190}$ suggesting that FEVR and ADNIV are allelic. If so, future identification of the locus will be necessary to explain why ADNIV is a phenotypically distinct disease characterised by developmentally normal retinal vessels. Other clinical characteristics that distinguish ADNIV from FEVR include ocular inflammation, retinal and iris 
neovascularisation, cystoid macular oedema, fundus pigmentation, and a selective loss of the ERG B wave.

When compared to autosomal dominant FEVR, the $\mathrm{X}$ linked recessive form of FEVR usually has an earlier onset of symptoms. The adult female gene carriers show no evidence of disease. Fullwood et $a l^{191}$ identified a family with $\mathrm{X}$ linked FEVR and mapped the responsible locus by linkage analysis to either $\mathrm{Xq} 21.3$ or Xp11.4-11.3. The Xp11.4-11.3 region also contains the Norrie disease gene which has been cloned. ${ }^{192} 193$ Norrie disease is an $\mathrm{X}$ linked recessive disorder characterised by retinal dysplasia followed by retinal detachment and blindness. Norrie disease is a neurodevelopmental disorder associated with other ocular abnormalities such as microphthalmia, cataract, corneal opacities, congenital blindness, and bulbar atrophy. Extraocular manifestations include progressive sensorineural hearing loss and variable degrees of mental retardation. The Norrie disease gene encodes a mucin-like protein with a tertiary structure similar to that of transforming growth factor $\beta^{194}$ and mutations within this gene have been identified in families with Norrie disease. ${ }^{195-200}$ Surprisingly, a point mutation within this Norrie disease gene was found to cosegregate in a family with $\mathrm{X}$ linked FEVR studied by Chen et al. ${ }^{201}$ This finding suggests that the genes for $\mathrm{X}$ linked FEVR and Norrie disease are allelic, and once again shows the phenomenon of "gene sharing" between phenotypically distinct diseases. Another disease known as primary retinal dysplasia also has a tight linkage relationship with the Norrie disease locus. ${ }^{202}$ Like FEVR and Norrie disease, primary retinal dysplasia is an $\mathrm{X}$ linked recessive disorder characterised by retinal detachment. The raised retinal fold characteristic of primary retinal dysplasia arises from the optic disc and involves the macula as it extends to the temporal fundus. Mutations responsible for primary retinal dysplasia have not as yet been reported.

\section{JUVENILE RETINOSCHISIS}

Juvenile retinoschisis (RS) is an X linked recessive disorder characterised by cystic degeneration of the peripheral and central retina resulting in the splitting of the nerve fibre layer. A cystic maculopathy with a stellate appearance is a characteristic finding in affected males. Phenotypic expression is highly variable but onset is usually during infancy and there is a slow deterioration throughout life with mild visual impairment until after the age of 40 . The disease progresses to retinal detachment, retinal atrophy, choroidal sclerosis, and possibly total blindness. Vasculature abnormalities and vitreous degeneration are associated features. Female carriers of this disease are usually asymptomatic. Multipoint linkage analysis has been used to map the gene responsible for this disease to within the $\mathrm{Xp22.1-22.2}$ locus. ${ }^{203-208}$ It is not known at this time if the variable expressivity of this disease can be explained on the basis of allelic heterogeneity, as the gene has not been identified.
WAGNER VITREORETINAI DEGENERATION

Wagner syndrome is an autosomal dominant disorder that has the same ocular features as Stickler syndrome but none of the non-ocular manifestations. Wagner syndrome is characterised by degeneration of the vitreous gel and the retina. These patients appear to have an optically empty vitreous cavity on slit lamp biomicroscopy. Other associated ocular features include retinal detachment, myopia, and cataract. Stickler syndrome has the additional features of progressive arthropathy, cranio-orofacial abnormalities, and deafness. It is unclear whether the Wagner and Stickler syndromes should be considered two distinct clinical disorders or whether they represent variable expressivity of one disease. This debate has been complicated by the fact that Stickler syndrome is a genetically heterogeneous disease. Some families with Stickler syndrome have defects in the COL2A1 gene that encodes for type II $\alpha$ procollagen. ${ }^{209-214}$ However, about half of the families reported so far with Stickler syndrome do not show cosegregation with the COL2A1 locus. ${ }^{215-218}$ To confuse the issue further, one family with Wagner syndrome has been excluded from the COL2A1 locus ${ }^{216}$ and another family has been linked to the COL2A 1 locus. ${ }^{219}$ Körkkö et $a l^{219}$ proposed that premature termination mutations within the COL2Al gene may cause the more severe Stickler syndrome while certain amino acid substitutions may cause a milder phenotype like Wagner syndrome. The extent of the relationship between the Stickler and Wagner syndromes remains to be resolved.

\section{Conclusion}

The primary genetic disorders of the retina, choroid, and vitreous discussed in this review are summarised along with their MIM (Mendelian inheritance in man) number in the accompanying table and idiograms. If a locus has been identified as a cause for a disorder, the MIM number for that disease is assigned according to the identified disease gene. The phenomenon of locus or non-allelic heterogeneity can be appreciated in the table by the different MIM numbers and genes that are assigned to the same clinical disorder. The prevalence of "gene sharing" allelism between clinically distinct disorders is evident by the repeated reference to the same gene or MIM number for different diseases and the presence of grouped disorders adjacent to a chromosomal location in the idiograms. This summary shows a genetic complexity to the mapping of ocular disorders that could not have been appreciated by using clinical classification schemes alone.

\section{Note added in proof}

Since this review was submitted, several noteworthy chromosomal loci associated with posterior segment ocular disorders have been published. A digenic form of retinitis pigmentosa was reported in three unrelated families. ${ }^{220}$ In these families, affected subjects were double heterozygotes with mutations in the 
unlinked peripherin/RDS and ROM1 genes. A heterozygous missense mutation in the rod cGMP phosphodiesterase $\beta$-subunit genes was reported to cosegregate with autosomal dominant stationary night blindness in one family. ${ }^{221}$ The Bardet-Biedl syndrome was mapped to a second locus on chromosome $11 \mathrm{q} .{ }^{222}$ An autosomal dominant macular degeneration known as Sorsby's fundus dystrophy was mapped to chromosome 22q13-qter. ${ }^{223}$ The locus for autosomal dominant cystoid macular dystrophy was mapped to chromosome $7 \mathrm{p} 15-$ p21. ${ }^{224}$

1 Tramboli A, Marvin JP, Horm JW. The incidence of retinoblastoma in the United States: 1974 through 1985. Arch Ophthalmol 1990;108:128-32.

2 Toguchida J, McGee TL, Paterson JC, et al. Complete genomic sequence of the human retinoblastoma susceptibility gene. Genomics 1993;17:535-43.

3 Dunn JM, Phillips RA, Becker AJ, et al. Identification of germline and somatic mutations affecting the retgermline and somatic mutations affecting
inoblastoma gene. Science 1988;241:1797-800

4 Dunn JM, Phillips RA, Zhu X, et al. Mutations in the RBI gene and their effects on transcription. Mol Cell Biol 1989; 9:4596-604.

5 Yandell DW, Campbell TA, Dayton SH, et al. Oncogenic point mutations in the human retinoblastoma gene: their application to genetic counseling. $N$ Engl $\mathcal{F}$ Med 1989; 321:1689-95.

6 Sakai T, Toguchida J, Ohtani N, et al. Allele-specific hypermethylation of the retinoblastoma tumor-suppressor gene. Am F Hum Genet 1991;48:880-8.

7 Hashimoto T, Takahashi R, Yandell DW, et al. Characterization of intragenic deletions in two sporadic germinal mutation cases of retinoblastoma resulting in abnormal gene expression. Oncogene 1991;6:463-9.

8 Kloss K, Währisch P, Greger V, et al. Characterization of deletions at the retinoblastoma locus in patients with bilateral retinoblastoma [see comments]. Am 7 Med Genet 1991;39:196-200.

9 Hogg A, Onadim Z, Baird PN, et al. Detection of heterozygous mutations in the RB1 gene in retinoblastoma patients using single-strand conformation polymorphism analysis and polymerase chain reaction sequencing. $O n$ cogene 1992;7:1445-51.

10 Lohmann D, Horsthemke B, Gillessen-Kaesbach G, et al. Detection of small RB1 gene deletions in retinoblastoma by multiplex PCR and high-resolution gel electrophoresis. Hum Genet 1992;89:49-53.

11 Hogg A, Bia B, Onadim Z, et al. Molecular mechanisms of oncogenic mutations in tumors from patients with bilateral and unilateral retinoblastoma. Proc Natl Acad Sci USA 1993;90:7351-5.

12 Blanquet V, Turleau C, Gross MS, et al. Identification of germline mutations in the RBl gene by denaturant gradient gel electrophoresis and polymerase chain reaction direct sequencing. Hum Mol Genet 1993;2:975-9.

13 Janson M, Nordenskjöld M. A constitutional mutation within the retinoblastoma gene detected by PFGE. Clin Wenet 1994;45:5-10.

14 Sakai T, Ohtani N, McGee TL, et al. Oncogenic germline mutations in Spl and ATF sites in the human retinoline mutations in Spl and ATF sites in the

15 Onadim Z, Hogg A, Baird PN, et al. Oncogenic point mutations in exon 20 of the RB1 gene in families showing ncomplete penetrance and mild expression of the retinoblastoma phenotype. Proc Natl Acad Sci USA 1992 89:6177-81.

16 Munier FL, Wang MX, Spence A, et al. Pseudo low penetrance in retinoblastoma. Arch Ophthalmol 1993;111: 1507-11.

17 Dryja TP, Rapaport J, McGee TL, et al. Molecular etiology of low-penetrance retinoblastoma in two pedigrees. $A m$ f Hum Genet 1993;52:1122-8.

18 Nathans J, Thomas D, Hogness DS Molecular genetics of human color vision: the genes encoding blue, green, and red pigments. Science 1986;232:193-202.

19 Vollrath D, Nathans J, Davis R. Tandem array of human visual pigment genes at Xq28. Science 1988;240:1669-72.

20 Feil R, Aubourg P, Helig R, et al. A 195-kb cosmid walk encompassing the human $\mathrm{Xq} 28$ color vision pigment encompassing the human Xq28

21 Nathans J, Piantanida TP, Eddy RL, et al. Molecular genetics of inherited variation in human color vision. genetics of inherited var $1986 ; 232: 203-10$.

22 Nathans J, Merbs SL, Sung CH, et al. Molecular genetics of human visual pigments. Annu Rev Genet 1992;26. 403-24.

23 Winderickx J, Battisti L, Hibiya Y, et al. Haplotype diversity in the human red and green opsin genes: evidence fo sequence exchange in exon 3. Hum Mol Genet 1993;2. 1413-21.

24 Winderickx J, Battisti L, Motulsky AG, et al. Selective expression of human $\mathrm{X}$ chromosome-linked green opsin genes. Proc Natl Acad Sci USA, 1992;89:9710-

25 Drummond-Borg M, Deeb S, Motulsky AG. Molecular basis of abnormal red-green color vision: a family with three types of color vision defects. Am f Hum Genet 1988; 43:675-83.

26 Neitz M, Neitz J, Jacobs GH. Analysis of fusion gene and encoded photopigment of colour-blind humans. Nature 1989;342:679-82.

27 Deeb SS, Lindsey DT, Hibiya Y, et al. Genotype-phenotype relationships in human red/green color-vision defects: molecular and psychophysical studies. Am $\mathcal{f}$ Hum Genet molecular and psycho

28 Zhang Q, Mao W, Ma Q, et al. Molecular basis of congenital color vision defects in Chinese patients. Ipn $\mathcal{F}$ Ophthalmo 1992:36:479-87.

29 Winderickx J, Sanocki E, Lindsey DT, et al. Defective colour vision associated with a missense mutation in the human green visual pigment gene. Nature Genet 1992;1 $251-6$

30 Oprian DD, Asenjor AB, Lee N, et al. Design, chemica synthesis, and expression of genes for the three human color vision pigments. Biochemistry 1991;30:11367-72.

31 Merbs SL, Nathans J. Absorption spectra of the hybrid pigments responsible for anomalous color vision. Science 1992;258:464-6.

32 Merbs SL, Nathans J. Absorption spectra of human cone pigments. Nature 1992;356:433-5.

33 Winderickx J, Lindsey DT, Sanocki E, et al. Polymorphism in red photopigment underlies variation in colour matching. Nature 1992;356:431-3.

34 Neitz J, Neitz M, Jacobs GH. More than three differen cone pigments among people with normal color vision. Vision Res 1993;33:117-22.

35 Hess RF, Mullen KT, Sharpe LT, et al. The photoreceptors in atypical achromotopsia. $\mathcal{f}$ Physiol 1989;417:123-49.

36 Reitner A, Sharpe LT, Zrenner E. Is colour vision possible with only rods and blue sensitive cones? Nature 1991 352:798-800.

37 Nathans J, Davenport CM, Maumenee IH, et al. Molecular genetics of human blue cone monochromacy. Science $1989 ; 245: 831-8$

38 Nathans J, Maumenee IH, Zrenner E, et al. Genetic heterogeneity among blue-cone monochromats. Am f Hum Genet 1993;53:987-1000.

39 Wang Y, Macke JP, Merbs SL, et al. A locus control region adjacent to the human red and green visual pigmen genes. Neuron 1992;9:429-40.

40 Fitzgibbon J, Appukuttan B, Gayther S, et al. Localisation of the human blue cone pigment gene to chromosome band 7q31.3-32. Hum Genet 1994;93:79-80.

41 Weitz CJ, Miyake Y, Shinzato K, et al. Human tritanopia associated with two amino acid substitutions in the bluesensitive opsin. Am f Hum Genet 1992;50:498-507.

42 Weitz CJ, Went LN, Nathans J. Human tritanopia associated with a third amino acid substitution in the bluesensitive visual pigment. Am ₹ Hum Genet 1992;51:444-6.

43 Falls HF, Wolter JR, Alpern M. Typical total monochromacy - a historical and psychophysical study. Arch Ophthalmol 1965;74:610-16.

44 Pentao L, Lewis RA, Ledbetter DH, et al. Maternal uniparental isodisomy of chromosome 14: association with autosomal recessive rod monochromacy. Am $\mathcal{F ~ H u m ~ G e n e}$ 1992;50:690-9.

45 Sieving PA, Richards JE, Bingham EL, et al. Dominan congenital complete nystalopia and Gly90Asp rhodopsin mutation. Invest Ophthalmol Vis Sci 1992;33:1397.

46 Dryja TP, Berson EL, Rao VR, et al. Heterozygous missense mutation in the rhodopsin gene as a cause of congenital
stationary night blindness. Nature Genet 1993;4:280-3.

47 Rao VK, Cohen GB, Oprian DD. Rhodopsin mutation G90D and a molecular mechanism for congenital night blindness. Nature 1994;367:639-42.

48 Musarella MA, Weleber RG, Murphey WH, et al. Assignment of the gene for complete $\mathrm{X}$-linked congenital stationary night blindness (CSNB1) to chromosome stationary night blindness 2 (CSN. Genomics 1989;5:727-37.

49 Aldred MA, Dry KL, Sharp DM, et al. Linkage analysis in $\mathrm{X}$-linked congenital stationary night blindness. Genomics 1992;14:99-104.

50 Bech-Hansen NT, Moore BJ, Pearce WG. Mapping of locus for X-linked congenital stationary night blindnes (CCNB1) proximal to DXS7. Genomics 1992;12:409-11.

51 Dry KL, Van DD, Aldred MA, et al. Linkage analysis in a family with complete type congenital stationary nigh blindness with and without myopia. Clin Genet 1993;43 250-4.

52 Coleman M, Bhattacharya S, Lindsay S, et al. Localization of the microsatellite probe DXS426 between DXS7 and DXS255 on Xp and linkage to X-linked retinitis pigmentosa. Am F Hum Genet 1990;47:935-40.

53 Wright AF, Bhattacharya SS, Aldred MA, et al. Genetic localisation of the RP2 type of X linked retinitis pig-
mentosa in a large kindred. 7 Med Genet 1991;28:453-7.

54 Schwartz M, Rosenberg T. Alland eye disease: linkage data. Genomics 1991;10:327-32.

55 Alitalo T, Kruse TA, Forsius H, et al. Localization of the Åland Island eye disease locus to the pericentromeric Aland Island eye disease locus to the pericentromeric
region of the $\mathrm{X}$ chromosome by linkage analysis. $A m \mathcal{F}$ region of the Xen chromosom $1991 ; 48: 31-8$.

56 Glass IA, Good P, Coleman MP, et al. Genetic mapping of a cone and rod dysfunction (Alland eye disease) to the proximal short arm of the human X chromosome. $\mathcal{F} \mathrm{Med}$ Genet 1993;30:1044-50.

57 Charles SJ, Green JS, Grant JW, et al. Clinical features of affected males with $\mathrm{X}$ linked ocular albinism. $\mathrm{Br} \mathcal{F}$ Ophthalmol 1993;77:222-7.

58 Charles SJ, Green JS, Moore AT, et al. Genetic mapping of X-linked ocular albinism: linkage analysis in a large 
Newfoundland kindred. Genomics 1993;16:259-61.

59 Bergen AA, Zijp P, Schuurman EJ, et al. Refinement of the localization of the X-linked ocular albinism gene. Genomics 1993;16:272-3.

60 Meindl A, Hosenfeld D, Bruckl W, et al. Analysis of a terminal Xp22.3 deletion in a patient with six monogenic disorders: implications for the mapping of $\mathrm{X}$ linked ocular albinism. F Med Genet 1993;30:838-42.

61 Bouloux PM, Kirk J, Munroe P, et al. Deletion analysis maps ocular albinism proximal to the steroid sulphatase locus. Clin Genet 1993;43:169-73.

62 Winship IM, Babaya M, Ramesar RS. X-linked ocular albinism and sensorineural deafness: linkage to Xp22.3 Genomics 1993;18:444-5.

63 Wapenaar MC, Bassi MT, Schaefer L, et al. The genes for $\mathrm{X}$-linked ocular albinism (OA1) and microphthalmia with linear skin defects (MLS): cloning and characterization of the critical regions. Hum Mol Genet 1993;2:947-52.

64 Weleber RG, Pillers DM, Powell BR, et al. Aland Island disease (Forsius-Eriksson syndrome) associated with contiguous gene syndrome at Xp21: similarity to incomplete congenital stationary night blindness. Arch Ophthalmol 1989;107:1170-9

65 Pillers DM, Towbin JA, Chamberlain JS, et al. Deletion mapping of Alland Island eve disease to Xp21 between mapping of Aland Island eye disease to Xp21 between DXS67 (B24) and Duchenne

66 Pillers DM, Weleber RG, Powell BR, et al. Áland Island eye disease (Forsius-Eriksson ocular albinism) and an Xp21 deletion in a patient with Duchenne muscula dystrophy, glyceral kinase deficiency, and congenital ad renal hypoplasia. Am f Med Genet 1990;36:23-8.

67 Rose NC, Menacker SJ, Schnur RE, et al. Ocular albinism in a male with $\operatorname{del}(6)$ (q13-q15): candidate region fo autosomal recessive ocular albinism? $A m \mathcal{F}$ Med Gene 1992;42:700-5.

68 Heckenlively JR. Retinitis pigmentosa. 1st ed. Philadelphia: J B Lippincott, 1988

69 McKusick VA. Mendelian inheritance in man. 10th ed. Baltimore; Johns Hopkins University Press, 1992.

70 Bhattacharya SS, Wright AL, Clayton JF, et al. Close genetic linkage between X linked retinitis pigmentosa and

71 Ott J, Bhattacharya S, Chen S, et al. Localizing multiple $\mathrm{X}$-chromosome linked retinitis pigmentosa loci using mulX-chromosome linked retinitis pigmentosa loci using mul-
tilocus homogeneity tests. Proc Natl Acad Sci USA 1990; 87:701-4.

72 Musarella MA, Anson-Cartwright L, Leal SM, et al. Multipoint linkage analysis and heterogeneity testing in twenty $\mathrm{X}$-linked retinitis pigmentosa families. Genomics 1990;8 286-96.

73 Dahl N, Sundvall M, Pettersson U, et al. Genetic mapping of loci for X linked retinitis pigmentosa. Clin Genet 1991 40:435-40.

74 Wright AF. Towards the identification of genes in $\mathrm{X}$ linked retinitis pigmentosa. Prog Retina Res 1990;9:197-227.

75 Kaplan J, Bonneau D, Frezal J, et al. Clinical and genetic heterogeneity in retinitis pigmentosa. Hum Genet 1990; 85:635-42.

76 Kaplan J, Pelet A, Martin C, et al. Phenotype-genotype correlations in X-linked retinitis pigmentosa. $\mathrm{F}$ Med Genet 1992;29:615-23.

77 Dryja TP, McGee TL, Reichel E, et al. A point mutation of the rhodopsin gene in one form of retinitis pigmentosa. Nature 1990;343:364-6.

78 Dryja TP, McGee TL, Hahn LB, et al. Mutations within the rhodopsin gene in patients with autosomal dominan the rhodopsin gene in patients with autosomal domina

79 Sung CH, Davenport CM, Hennessey JC, et al. Rhodopsin mutations in autosomal dominant retinitis pigmentosa. Proc Natl Acad Sci USA 1991;88:6481-5.

80 Inglehearn CF, Bashir R, Lester DH, et al. A 3-bp deletion in the rhodopsin gene in a family with autosomal dominant retinitis pigmentosa. Am f Hum Genet 1991;48 $26-30$

81 Gal A, Artlich A, Ludwig M, et al. Pro-347-Arg mutation of the rhodopsin gene in autosomal dominant retinitis pigmentosa. Genomics 1991;11:468-70.

82 Farrar GJ, Kenna P, Redmond R, et al. Autosomal dominant retinitis pigmentosa: a mutation in codon 178 of the rhodopsin gene in two families of celtic origin. Genomics 1991;11:1170-1.

83 Sheffield VC, Fishman GA, Beck JS, et al. Identification of novel rhodopsin mutations associated with retinitis pigmentosa by GC-clamped denaturing gradient gel electrophoresis. Am f Hum Genet 1991;49:699-706.

84 Keen TJ, Inglehearn CF, Lester DH, et al. Autosomal dominant retinitis pigmentosa: four new mutations in dominant retinitis pigmentosa: four new mutations in
rhodopsin, one of them in the retinal attachment site. rhodopsin, one of them in

85 Richards JE, Kuo CY, Boehnke $M$, et al. Rhodopsin Thr58Arg mutation in a family with autosomal dominan retinitis pigmentosa. Ophthalmology 1991;98:1797-805. 86 Bhattacharya S, Lester D, Keen J, et al. Retinitis pig-

87 Dryja TP, Hahn LB, Cowley GS, et al. Mutation spectrum of the rhodopsin gene among patients with autosomal dominant retinitis pigmentosa. Proc Natl Acad Sci USA 1991;88:9370-4.

88 Inglehearn CF, Keen TJ, Bashir R, et al. A completed screen for mutations of the rhodopsin gene in a panel of patients with autosomal dominant retinitis pigmentosa. Hum Mol Genet 1992;1:41-5.

89 Andréasson S, Ehinger B, Abrahamson M, et al. A sixgeneration family with autosomal dominant retinitis pig-
mentosa and a rhodopsin gene mutation (arginine-135leucine). Ophthalmic Paediatr Genet 1992;13:145-53.

90 Artlich A, Horn M, Lorenz B, et al. Recurrent 3-bp deletion at codon $255 / 256$ of the rhodopsin gene in a German pedigree with autosomal dominant retinitis pigmentosa. Am 7 Hum Genet 1992;50:876-8.

91 Farrar GJ, Findlay JB, Kumar SR, et al. Autosomal dominant retinitis pigmentosa: a novel mutation in the rhodopsin gene in the original 3q linked family. Hum $\mathrm{Mol}$

92 Fishman GA, Stone EM, Gilbert LD, et al. Ocular findings associated with a rhodopsin gene codon 106 mutation: glycine-to-arginine change in autosomal dominant retinitis pigmentosa. Arch Ophthalmol 1992;110:646-53.

93 Fujiki K, Hotta Y, Hayakawa M, et al. Point mutations of rhodopsin gene found in Japanese families with autosomal dominant retinitis pigmentosa (ADRP). fpn $\mathcal{f} \mathrm{Hum}$ Genet 1992;37:125-32.

94 Horn M, Humphries P, Kunisch M, et al. Deletions in exon 5 of the human rhodopsin gene causing a shift in the reading frame and autosomal dominant retinitis pigmentosa. Hum Genet 1992;90:255-7.

95 Rodriguez JA, Herrena C, Birch DG, et al. A leucine to arginine amino acid substitution at codon 46 of rhodopsin gene is responsible for a severe form of autosomal domgene is responsible for a severe form of autosomal dom-
inant retinitis pigmentosa. Hum Mutat 1993;2:205-13.

96 Sullivan LJ, Makris GS, Dickinson P, et al. A new codon 15 rhodopsin gene mutation in autosomal dominant retinitis pigmentosa is associated with sectorial disease. Arch Ophthalmol 1993;111:1512-7.

97 Bunge S, Wedemann H, David D, et al. Molecular analysis and genetic mapping of the rhodopsin gene in families with autosomal dominant retinitis pigmentosa. Genomics 1993;17:230-3

98 Hayakawa M, Hotta Y, Imai Y, et al. Clinical features of autosomal dominant retinitis pigmentosa with rhodopsin gene codon 17 mutation and retinal neovascularization in a Japanese patient. Am $\mathcal{F}$ Ophthalmol 1993;115:168-73.

$99 \mathrm{Kim} \mathrm{RY}, \mathrm{Al} \mathrm{MM}$, Fitzke FW, et al. Dominant retinitis pigmentosa associated with two rhodopsin gene mutations. Leu-40-Arg and an insertion disrupting the 5-splice .

100 Restangno G, Maghtheh M, Bhattacharya S, et al. A large deletion at the $3^{\prime}$ end of the rhodopsin gene in an Italian family with a diffuse form of autosomal dominant retinitis pigmentosa. Hum Mol Genet 1993;2:207-8.

101 Macke JP, Davenport CM, Jacobson SG, et al. Identification of novel rhodopsin mutations responsible for retinitis pigmentosa: implications for the structure and function of rhodopsin. Am f Hum Genet 1993;53:80-9.

102 Vaithinathan R, Berson EL, Dryja TP. Further screening of the rhodopsin gene in patients with autosomal dominant retinitis pigmentosa. Genomics 1994;21:461-3.

103 Al-Maghtheh M, Kim RY, Hardcastle A, et al. A 150 bp insertion in the rhodopsin gene of an autosomal dominan retinitis pigmentosa family. Hum Mol Genet 1994;3:205-6.

104 Reig C, Liecha N, Antich J, et al. A missense mutation (His211Arg) and a silent (Thr160) mutation within the rhodopsin gene in a Spanish autosomal dominant retiniti
pigmentosa family. Hum Mol Genet 1994;3:195-6.

105 Macke JP, Nathans J, Rosas DJ, et al. A molecular genetic study on an extensive Argentinian pedigree with autosomal dominant retinitis pigmentosa. Invest Ophthalmol Vis $S_{c i}$ 1994;35:1716.

106 Kajiwara K, Hahn LB, Mukai S, et al, Mutations in the human retinal degeneration slow gene in autosomal the human retinal degeneration slow gene in autosomal
dominant retinitis pigmentosa. Nature 1991;354:480-2.

107 Farrar GJ, Kenna P, Jordan SA, et al. Autosomal dominant retinitis pigmentosa: a novel mutation at the peripherin/ RDS locus in the original 6p-linked pedigree. Genomics 1992;14:805-7.

108 Wells J, Wroblewski J, Keen J, et al. Mutations in the human retinal degeneration slow (RDS) gene can cause either retinitis pigmentosa or macular dystrophy. Nature Genet 1993;3:213-8.

109 Weleber RG, Carr RE, Murphey WH, et al. Phenotypic variation including retinitis pigmentosa, pattern dystrophy, and fundus flavimaculatus in a single family with a deletion of codon 153 or 154 of the peripherin/RDS gene. Arch Ophthalmol 1993;111:1531-42.

110 Farrar GJ, Kenna P, Jordan SA, et al. Autosomal dominant retinitis pigmentosa: a novel mutation at the peripherin/ RDS locus in the original 6p-linked pedigree (errata). Genomics 1993;15:466.

111 Saga M, Mashima Y, Akeo K, et al. A novel Cys-214-Ser mutation in the peripherin/RDS gene in a Japanese family with autosomal dominant retinitis pigmentosa. Hum Genet 1993;92:519-21.

112 Kajiwara K, Sandberg MA, Berson EL, et al. A null mutation in the human peripherin/RDS gene in a family with autosomal dominant retinitis punctata albescens [see comments]. Nature Genet 1993;3:208-12.

113 Nichols BE, Sheffield VC, Vandenburgh K, et al. Butterflyshaped pigment dystrophy of the fovea caused by a point mutation in codon 167 of the RDS gene [see comments]. Nature Genet 1993;3:202-7.

14 Nichols BE, Drack AV, Vandenburgh K, et al. A 2 base pair deletion in the RDS gene associated with butterflyshaped pigment dystrophy of the fovea. Hum Mol Genet 1993;2:601-3.

115 Travis GH, Christerson L, Danielson PE, et al. The human retinal degeneration slow (RDS) gene: chromosome assignment and structure of the mRNA. Genomics 1991; 10:733-9. 
116 Jordan SA, Farrar GJ, Kumar SR, et al. Autosomal dominant retinitis pigmentosa (adRP; RP6): cosegregation of RP6 and the peripherin-RDS locus in a late-onset family of Irish origin. Am ₹ Hum Genet 1992;50:634-9.

117 Blanton SH, Heckenlively JR, Cottingham AW, et al. Linkage mapping of autosomal dominant retinitis pigmentosa (RP1) to the pericentric region of human chromosome 8. Genomics $1991 ; 11: 857-69$.

118 Inglehearn CF, Carter SA, Keen TF, et al. A new locus for autosomal dominant retinitis pigmentosa on chromosome 7p Nature Genet 1993;4:51-3.

118A Inglehearn CF, Keen TJ, Al-Maghtheh M, et al. Further refinement of the location for autosomal dominant retinitis pigmentosa on chromosome 7p (RP9). Am $\mathcal{f}$ Hum Genet 1994;54:675-80.

119 Jordan SA, Farrar GJ, Kenna P, et al. Localization of an autosomal dominant retinitis pigmentosa gene to chromosome 7q. Nature Genet 1993;4:54-8.

120 Al-Maghtheh M, Inglehearn CF, Keen TJ, et al. Identification of a sixth locus for autosomal dominant retinitis pigmento

121 Kumar-Singh R, Farrar GJ, Mansergh F, et al. Exclusion of the involvement of all known retinitis pigmentosa loci in the disease present in a family of Irish origin provides in the disease present in a family of Irish origin provides evidence for a sixth autosomal

122 Rosenfeld PJ, Cowley GS, McGee TL, et al. A Null mutation in the rhodosin gene causes rod photoreceptor dysfunction and autosomal recessive retinitis pigmentosa Nature Genet 1992;1:209-13.

123 McLaughlin ME, Sandberg MA, Berson EL, et al. Recessive mutations in the gene encoding the beta-subunit of rod phosphodiesterase in patients with retinitis pigmentosa. Nature Genet 1993;4:130-4.

124 McLaughlin ME, Ehrhart TL, Sandberg MA, et al. Mutations in the beta subunit of rod phosphodiesterase in patients with autosomal recessive retinitis pigmentosa Invest Ophthalmol Vis Sci 1994;35:1718.

125 Rosenfeld PJ, Hahn LB, Miller S, et al. A rhodopsin splice site mutation: recessive or dominant? Invest Ophthalmol Sis $S c i$ 1994;35:1478.

$126 \mathrm{McGee}$ TL, Lin D, Berson EL, et al. Defects in the rod cGMP-gated channel gene in patients with retinitis pigmentosa. Invest Ophthalmol Vis Sci 1994;35:1716.

127 Kaplan J, Gerber S, Bonneau D, et al. A gene for Usher syndrome type I (USH1A) maps to chromosome 14q. Genomics 1992;14:979-87.

128 Smith RJH, Lee EC, Kimberling WJ, et al. Localization of two genes for Usher syndrome type I to chromosome 11. Genomics 1992;14:995-1002.

129 Kimberling WJ, Möller CG, Davenport S, et al. Linkage of Usher syndrome type I gene (USH1B) to the long arm of chromosome 11. Genomics 1992;14:988-94.

130 Ayyagari R, Smith RJH, Polymeropoulos M, et al. Linkage and haplotype analysis and physical mapping of the and haplotype analysis and physical mapping of the

131 Kimberling WJ, Weston MD, Möller C, et al. Localization of Usher syndrome type II to chromosome 1q. Genomics of Usher syndrom

132 Lewis RA, Otterud B, Stauffer D, et al. Mapping recessive ophthalmic diseases: linkage of the locus for Usher syndrome type II to a DNA marker on chromosome 1q Genomics 1990; 7:250-6.

133 Bokhoven HV, Genderen CV, Molloy CM, et al. Mapping of the choroideremia-like (CHML) gene at 1q42-qte and mutation analysis in patients with Usher syndrome type II. Genomics 1994;19:385-7.

134 Pieke Dahl S, Kimberling WJ, Gorin MB, et al. Genetic heterogeneity of Usher syndrome type II. $\mathcal{F}$ Med Genet 1993;30:843-8.

135 Kwitek-Black AE, Carmi R, Duyk GM, et al. Linkage of Bardet-Biedl syndrome to chromosome $16 \mathrm{q}$ and evidence for non-allelic heterogeneity. Nature Genet 1993;5:392-6.

136 Sheffield VC, Kwitek-Black A, Carmi R, et al. Homozygosity mapping of the gene for Bardet-Biedl syndrome zygosity mapping of the gene for Bardet-Biedl syndrome in large

137 Reichel E, Bruce AM, Sandberg MA, et al. An electroretinographic and molecular genetic study of X-linked cone degeneration. Am $\mathcal{f}$ Ophthalmol 1989;108:540-7.

138 Bartley J, Gies C, Jacobsen D. Cone dystrophy (X-linked) (COD1) maps between DXS7(L1.28) and DXS206 XJ1.1) and is linked to DXS84(754). Cytogenet Cell Genet 1989;51:959.

138A Meire FM, Bergen AAB, De Rouck A, et al. X linked progressive cone dystrophy: localization of the gene locus to Xp21-p11.1 by linkage analysis. Br $\mathcal{F}$ Ophthalmol 1994 78:103-8.

139 Tranebjaerg L, Sjo O, Warburg M. Retinal cone dysfunction and mental retardation associated with a de novo balanced translocation 1;6 (q44;q27). Ophthal Paediatr Genet 1986;7:167-73.

140 Warburg M, Sjo O, Tranebjaerg L, et al. Deletion of a retinal cone-rod dystrophy: assignment to $18 \mathrm{q} 211 . \mathrm{Am} \mathfrak{f}$ Med Genet 1991;39:288-93.

141 Evans K, Fryar A, Inglehearn C, et al. Genetic linkage of cone-rod retinal dystrophy to chromosome $19 \mathrm{q}$ and of cone-rod retinal dystrophy to chromosome $19 \mathrm{q}$ and evidence

142 Kylstra JA, Aylsworth AS. Cone-rod retinal dystrophy in a patient with neurofibromatosis type I. Can $\mathcal{F}$ Ophthalmol 1993;28:79-80.

143 Small KW, Weber JL, Roses A, et al. North Carolina macular dystrophy is localized to 6q14-q16.2. Am $7 \mathrm{Hum}$ Genet 1992;51(suppl):A34.

144 Small KW, Weber JL, Roses A, et al. North Carolina macular dystrophy is assigned to chromosome 6. Genomics 1992;13:681-5.

144A Small KW, Weber J, Roses A, et al. North Carolina macular dystrophy (MCDRI). A review and refined mapping to 6q14-q16.2. Ophthalmic Paediatr Genet 1993;14 ping to

145 Small KW, Sanchez AR, Yelchits SV, et al. Physical mapping of the MCDR1 (North Carolina macular dystrophy) locus. Invest Ophthalmol Vis Sci 1994;35:1717.

146 Stone EM, Nichols BE, Streb LM, et al. Genetic linkage of vitelliform macular degeneration (Best's disease) to chromosome 11q13. Nature Genet 1992;1:246-50.

147 Ferrell RE, Hittner HM, Antoszyk JH. Linkage of atypica vitelliform macular dystrophy (VMD-1) to the soluble glutamate pyruvate transaminase (GPT1) locus. $\mathrm{Am} \mathcal{f}$ Hum Genet 1983;35:78-84.

148 Keen TJ, Inglehearn CF, Kim R, et al. Retinal pattern dystrophy associated with a $4 \mathrm{bp}$ insertion at codon 140 in the RDS-peripherin gene. Hum Mol Genet 1994:3: $367-8$.

149 Kaplan J, Gerber S, Larget-Piet D, et al. A gene for Stargardt's disease (fundus flavimaculatus) maps to the short arm of chromosome 1. Nature Genet 1993;5:308-11.

150 Kaplan J, Gerber S, Larget-Piet D, et al. A gene for Stargardt's disease (fundus flavimaculatus) maps to the short arm of chromosome 1 (correction). Nature Genet 1994;6:214.

151 Zhang K, Bither PP, Park R, et al. A dominant Stargardt's macular dystrophy locus maps to chromosome 13q34. Arch Ophthalmol 1994;112:759-64.

152 Stone EM, Nichols BE, Kimura AE, et al. Clinical features of a Stargardt-like dominant progressive macular dystrophy with genetic linkage to chromosome 6q. Arch Ophthalmol 1994;112:765-72.

153 Cremers PM, van de Pol DJR, Kerkhoff LPM, et al. Cloning of a gene that is rearranged in patients with choroideremia. Nature 1990;347:674-7.

154 Merry DE, Jänne PA, Landers JE, et al. Isolation of a candidate gene for choroideremia. Proc Natl Acad $S_{c i}$ USA 1992;89:2135-9.

155 van den Hurk JAJM, van de Pol TJR, Molloy CM, et al. Detection and characterization of point mutations in the choroideremia candidate gene by PCR-SSCP analysis and direct DNA sequencing. Am 7 Hum Genet 1992;50: and direct

156 Sankila EM, Tolvanen R, van den Hurk JAJM, et al. Aberrant splicing of the CHM gene is a significant cause Aberrant splicing of the CHM gene is a significa

157 Schwartz M, Rosenberg T, van den Hurk JAJM, et al. Identification of mutations in Danish choroideremia families. Hum Mutat 1993;2:43-7.

158 Pascal O, Donnelly P, Fouanon C, et al. A new (old) deletion in the choroideremia gene. Hum Mol Genet 1993 1:1489.

159 Matsui Y, Kikuchi A, Araki S, et al. Molecular cloning and characterization of a novel type of regulatory protein (GDI) for smg p25A, a ras p21-like GTP-binding protein. Mol Cell Biol 1990;10:4116-22.

160 Fodor E, Lee RT, O'Donnell JJ. Analysis of choroideraemia gene (letter). Nature 1991;351:614.

161 Cremers FP, Molloy CM, van de Pol DJR, et al. An autosomal homologue of the choroideremia gene colocalizes with the Usher syndrome type II locus on the distal part of chromosome 1q. Hum Mol Genet 1992;1: $71-5$.

162 Seabra MC, Brown MS, Slaughter CA, et al. Purification of component A of Rab geranylgeranyl transferase: possible identity with the choroideremia gene product. Cell 1992; identity with

163 Seabra MC, Brown MS, Goldstein JL. Retinal degeneration in choroideremia: deficiency of Rab geranylgeranyl transferase. Science 1993:259:377-81.

164 Valle D, Kaiser-Kupfer MI, Valle LAD. Gyrate atrophy of the choroid and retina: deficiency of ornithine aminotransferase in transformed lymphocytes. Proc Natl Acad Sci USA 1977;74:5159-61.

165 Inana G, Hotta Y, Zintz C, et al. Molecular basis of ornithine aminotransferase defect in gyrate atrophy. Prog Clin Biol Res 1991;362:191-219.

166 Ramesh V, Gusella JF, Shih VE. Molecular pathology of gyrate atrophy of the choroid and retina due to ornithine aminotransferase deficiency. Mol Biol Med 1991;8:81-93.

167 Ramesh V, Eddy R, Bruns GA, et al. Localization of the ornithine aminotransferase gene and related sequences

168 Barrett DJ, Bateman JB, Sparkes RS, et al. Chromosoma localization of human ornithine aminotransferase gene sequences to $10 \mathrm{q} 26$ and Xp11.2. Invest Ophthalmol Vis Sci 1 987;28: $1037-42$.

169 W/ J, Ramesh V, Kidd JR et al The ornithine am inotransferase (OAT) locus is linked and distal to D10S20 on the long arm of chromosome 10. Cytogenet Cell Genet $1988 ; 48: 126-7$.

170 Ramesh V, Benoit LA, Crawford P, et al. The ornithine aminotransferase (OAT) locus: analysis of RFLPs in aminotransferase (OAT) locus: analysis of RFLPs

171 Mitchell GA, Looney JE, Brody LC, et al. Human ornithine-delta aminotransferase: cDNA cloning and analysis of the structural gene. $\mathcal{F}$ Biol Chem 1988;263 14288-95.

172 Mitchell G, Brody L, Looney J, et al. An initiator codon mutation in ornithine-delta-aminotransferase causin 
gyrate atrophy of the choroid and retina. 7 Clin Invest 1988;81:630-3.

173 Ramesh V, McClatchey AI, Ramesh N, et al. Molecular basis of ornithine aminotransferase deficiency in B-6 responsive and -nonresponsive forms of gyrate atrophy. Proc Natl Acad Sci USA 1988;85:3777-80.

174 Inana G, Hotta Y, Zintz C, et al. Expression defect of ornithine aminotransferase gene in gyrate atrophy. Inves Ophthalmol Vis Sci 1988;29:1001-5.

175 Mitchell GA, Brody LC, Sipila I, et al. At least two mutant alleles of ornithine-delta-aminotransferase cause gyrate atrophy of the choroid and retina in Finns. Proc Natl Acad Sci USA 1989;86:197-201.

176 Inana G, Chambers C, Hotta Y, et al. Point mutation affecting processing of the ornithine aminotransferase precursor protein in gyrate atrophy. $\mathcal{F}$ Biol Chem 1989; 264:17432-6.

177 McClatchey AI, Kaufman DL, Berson E, et al. Splicing defect at the ornithine aminotransferase (OAT) locus in

178 Mitchell GA, Labuda D, Fontaine G, et al. Splice-mediated insertion of an Alu sequence inactivates ornithine deltaaminotransferase: a role for Alu elements in human mutation. Proc Natl Acad Sci USA 1991;88: 815-19.

179 Akaki Y, Hotta Y, Mashima Y, et al. A deletion in the ornithine aminotransferase gene in gyrate atrophy. $f$ Biol Chem 1992;267:12950-4.

180 Michaud J, Brody LC, Steel G, et al. Strand-separating conformational polymorphism analysis: efficacy of detection of point mutations in the human ornithine deltatection of point mutations in the human ornithine

181 Mashima Y, Weleber RG, Kennaway NG, et al. A singlebase change at a splice acceptor site in the ornithine aminotransferase gene causes abnormal RNA splicing in gyrate atrophy. Hum Genet 1992;90:305-7.

182 Mashima Y, Murakami A, Weleber RG, et al. Nonsensecodon mutations of the ornithine aminotransferase gene with decreased levels of mutant mRNA in gyrate atrophy. Am F Hum Genet 1992;51:81-91.

183 Park JK, Herron BJ, O'Donnell JJ, et al. Three novel mutations of the ornithine aminotransferase (OAT) gene in gyrate atrophy. Genomics 1992;14:553-4.

184 Park JK, O'Donnell JJ, Shih VE, et al. A 15-bp deletion in exon 5 of the ornithine aminotransferase (OAT) locus in exon 5 of the ornithine aminotransferase (OAT) locus

185 Brody LC, Mitchell GA, Obie C, et al. Ornithine deltaaminotransferase mutations in gyrate atrophy: allelic heterogeneity and functional consequences. $\mathcal{F}$ Biol Chem 1992;267:3302-7.

186 Dietz HC, Valle D, Francomano CA, et al. The skipping of constitutive exons in vivo induced by nonsense mutations. Science 1993;259:680-3.

187 Inana G, Hotta Y, Mashima Y, et al. Molecular genetic basis of gyrate atrophy. Invest Ophthalmol Vis Sci 1994 35:1984

$188 \mathrm{Li} \mathrm{Y}$, Muller B, Fuhrmann C, et al. The autosomal dominant familial exudative vitreoretinopathy locus maps on $11 \mathrm{q}$ and is closely linked to D11S533. Am $\mathfrak{f}$ Hum Genet $11 \mathrm{q}$ and is closely

$189 \mathrm{Li} \mathrm{Y}$, Fuhrmann C, Schwinger E, et al. The gene for autosomal dominant familial exudative vitreoretinopathy (Criswick-Schepens) on the long arm of chromosome 11 [letter]. Am F Ophthalmol 1992;113:712-3.

190 Stone EM, Kimura AE, Folk JC, et al. Genetic linkage of autosomal dominant neovascular inflammatory vitreoretinopathy to chromosome 11q13. Hum Mol Genet 1992, 1:685-9.

191 Fullwood P, Jones J, Bundey S, et al. X linked exudative vitreoretinopathy: clinical features and genetic linkage analysis. Br f Ophthalmol 1993;77:168-70.

192 Berger W, Meindl A, van de Pol, TJR, et al. Isolation of a candidate gene for Norrie disease by positional cloning. candidate gene for Norrie dise
Nature Genet 1992;1:199-203.

193 Chen Z, Hendriks RW, Jobling MA, et al. Isolation and characterization of a candidate gene for Norrie disease. Nature Genet 1992;1:204-8.

194 Meitinger T, Meindl A, Bork P, et al. Molecular modelling of the Norrie disease protein predicts cystine knot growth factor tertiary structure. Nature Genet 1993;5:376-80.

195 Berger W, van de Pol D, Warburg M, et al. Mutations in the candidate gene for Norrie disease. Hum Mol Genet 1992;1:461-5.

196 Meindl A, Berger W, Meitinger T, et al. Norrie disease is caused by mutations in an extracellular protein resembling C-terminal globular domain of mucins. Nature Genet 1992;2:139-43.

197 Chen Z, Battinelli EM, Hendricks RW, et al. Norrie disease gene: characterization of deletions and possible function Genomics 1993;16:533-5.

198 Chen Z, Battinelli EM, Woodruff G, et al. Characterization of a mutation within the NDP gene in a family with a manifesting female carrier. Hum Mol Genet 1993;2: 1727-9.

199 Wong F, Goldberg MF, Hao Y. Identification of a nonsense mutation at codon 128 of the Norrie disease gene in a male infant. Arch Ophthalmol 1993;111:1553-7.

$200 \mathrm{Zhu}$ D, Maumenee IH. Mutation analysis of the Norrie disease gene in eleven families. Invest Ophthalmol Vis $\mathrm{Sc}_{\mathrm{i}}$ 1994;35:1265.

201 Chen Z, Battinelli EM, Fielder A, et al. A mutation in the Norrie disease gene (NDP) associated with X-linked familial exudative vitreoretinopathy. Nature Genet 1993 5:180-3.

202 Ravia Y, Braier-Goldstein O, Bat-Miriam KM, et al. Xinked recessive primary retinal dysplasia is linked to the Norrie disease locus. Hum Mol Genet 1993;2:1295-7. 203 Sieving PA, Bingham E, Roth MS, et al. Linkage rep22.3 probes. Am $\mathcal{F}$ Hum Genet 1990;47:616-21.

204 Alitalo T, Kruse TA, de la Chapelle A. Refined localization of the gene causing $\mathrm{X}$-linked juvenile retinoschisis. Genomics 1991;9:505-10.

205 Alitalo T, Kruse TA, Ahrens P, et al. Genetic mapping of 12 marker loci in the Xp22.3-21.2 region. Hum Genet 12 marker loci in

206 Kaplan J, Pelet A, Hentati H, et al. Contribution to carrier detection and genetic counselling in $\mathrm{X}$ linked retinodetection and genetic counselling in
schisis. $\mathcal{F}$ Med Genet 1991;28:383-8.

207 Oudet C, Weber C, Kaplan J, et al. Characterisation of a highly polymorphic microsatellite at the DXS207 locus: confirmation of very close linkage to the retinoschisi disease gene. $f$ Med Genet 1992;30:300-3.

208 Bergen AA, van Schooneveld MJ, Orth U, et al. Multipoin linkage analysis in X-linked juvenile retinoschisis. Clin Genet 1993;43:113-6.

209 Francomano C, Liberfarb RM, Hirose T, et al. The Stickler syndrome: evidence for close linkage to the structural gene for type II collagen. Genomics 1987;1:293-6.

210 Priestley L, Kumar D, Sykes B. Amplification of the COL2A1 3-prime variable region used for segregation analysis in a family with the Stickler syndrome. Hum Genet 1990;85:525-6.

211 Ahmad NN, Ala-Kokko L, Knowlton RG, et al Stop codon in the procollagen II gene (COL2A1) in the family with the Stickler syndrome (arthro-ophthalmopathy). Proc Natl Acad Sci USA 1991;88:6624-7.

212 Brown DM, Nichols BE, Weingeist TA, et al. Procollagen II gene mutation in Stickler syndrome. Arch Ophthalmo

213 Ahmad NN, McDonald-McGinn DM, Zackai EH, et al. A second mutation in the type II procollagen gene (COL2A1) causing the Stickler syndrome (arthro-ophthalmopathy) is also a premature termination codon. $A m$ f Hum Genet 1993;52:39-45.

214 Brown DM, Vandenburgh K, Nichols BE, et al. Incidence of frameshift mutations in the procollagen II gene in Stickler syndrome and identification of four new mutations. Invest Ophthalmol Vis Sci 1994;35:1717.

215 Knowlton RG, Weaver EJ, Struyk AF, et al. Genetic linkage analysis of hereditary arthro-ophthalmopathy (Stickler syndrome) and the type II procollagen gene. Am $\mathcal{f} \mathrm{Hum}$ Genet 1989;45:681-8.

216 Fryer AE, Upadhyaya $M$, Littler $M$, et al. Exclusion of COL2A1 as a candidate gene in a family with WagnerStickler syndrome. 7 Med Genet 1990;27:91-3.

217 Vintiner GM, Temple K, Middleton-Price HR, et al. Genetic and clinical heterogeneity of Stickler syndrome. Am 1991;41:44-8.

218 Bonaventure J, Philippe C, Plessis G, et al. Linkage study in a large pedigree with Stickler syndrome: exclusion of COL2A1 as the mutant gene. Hum Genet 1992;90:164-8.

219 Körkkö J, Ritvaniemi P, Haataja L, et al. Mutation in type II procollagen (COL2A1) that substitutes aspartate for glycine alpha 1-67 and that causes cataracts and retinal detachment: evidence for molecular heterogeneity in the Wagner syndrome and the Stickler syndrome (arthroophthalmopathy). Am f Hum Genet 1993;53:55-61.

220 Kajiwara K, Berson EL, Dryja TP. Digenic retinitis pigmentosa due to mutations at the unlinked peripherin RDS and ROM1 loci. Science 1994;264:1604-8.

$221 \mathrm{Gal} A$, Orth U, Baehr W, et al. Heterozygous missense mutation in the rod cGMP phosphodiesterase $\beta$-subunit gene in autosomal dominant stationary night blindness. Nature Genet 1994;7:64-8.

222 Leppert $M$, Baird L, Anderson $\mathrm{KL}$, et al. Bardet-Biedl syndrome is linked to DNA markers on chromosome $11 \mathrm{q}$
and is genetically heterogeneous. Nature Genet 1994;7: and is $\mathrm{g}$.

223 Weber BHF, Vogt G, Wolz W, et al. Sorsby's fundus dystrophy is genetically linked to chromosome 22q13qter. Nature Genet 1994;7:158-61.

224 Kremer H, Pinckers A, van den Helm B, et al. Localization of the gene for dominant cystoid macular dystrophy on chromosome 7p. Hum Mol Genet 1994;3:299-302. 